\title{
KONSEP PENDIDIKAN IMAM ZARNUJI DAN PAULO FREIRE
}

\author{
Hanik Yuni Alfiyah \\ (Dosen FAI Universitas Sunan Giri)
}

\begin{abstract}
Abstrak
Tulisan ini bermaksud mengkaji konsep pendidikan Imam Zarnuji dan Paulo Freire. Mengkaji pemikiran pendidikan Imam Zarnuji dan Paulo Freire memang amat menarik, karena keduanya memiliki kekuatan masingmasing. Imam Zarnuji merupakan seorang filosof muslim dalam hal pendidikan yang ide-idenya kental dengan pesan-pesan moral. Menurutnya, selama ini peserta didik banyak menemukan kegagalan dalam hal kompetensi moral. Sehingga banyak alumni-alumni lembaga pendidikan yang cerdas tetapi kurang bermoral. Sementara itu Paulo Freire merupakan filosof pendidikan Barat yang ide-idenya kental dengan pesan-pesan pembebasan dalam pendidikan. Pendidikan harus memanusiakan manusia. Pendidikan harus membebaskan dan dapat menyelesaikan realitas problem sosial kemanusiaan. Membandingkan pemikiran pendidikan Zarnuji dengan Freire akan menemukan banyak perbedaan, karena memang mereka hidup dalam latar belakang sosial budaya yang berbeda, disamping juga paradigma keduanya yang berbeda. Hal yang menarik ketika memadukan pemikiran keduanya. Apabila melakukan pemaduan di antara kedua pemikiran tokoh tersebut, akan dapat menemukan konsep pendidikan yang humanis, membebaskan dan penuh dengan nuansa moral-transensdensi.
\end{abstract}

Kata Kunci: Pendidikan Zarnuji, Pendidikan Freire, dan Komparasi. 


\section{A. Pendahuluan}

Mengkaji persoalan mengenai pendidikan memang selalu menarik dan tidak ada habisnya, apalagi konsep pendidikan yang terakit dengan moral dan realitas sosial kemanusiaan. Konsep pendidikan yang bersifat teoritis ansich sering agak menjenuhkan, tetapi konsep pendidikan yang dihubungkan dengan persoalan eksistensial kemanusiaan akan selalu kurang memuaskan. Dalam kaitan ini, konsep pendidikan yang amat kental dengan muatan moral adalah ide-ide pendidikan yang dikemukakan oleh Imam Zarnuji. Sementara itu pendidikan yang terkait dengan problem-problem sosial kemanusiaan adalah konsep pendidikan Paulo Freire.

Imam Zarnuji merupakan seorang filosof muslim dalam hal pendidikan yang ide-idenya kental dengan pesan-pesan moral. Menurutnya, selama ini peserta didik banyak menemukan kegagalan dalam hal kompetensi moral. Sehingga banyak alumni-alumni lembaga pendidikan yang cerdas tetapi kurang bermoral. Sementara itu Paulo Freire merupakan filosof pendidikan Baarat yang ide-idenya kental dengan pesan-pesan pembebasan dalam pendidikan. Pendidikan harus memanusiakan manusia. Pendidikan harus membebaskan dan dapat menyelesaikan realitas problem sosial kemanusiaan.

\section{B. Konsep Pendidikan Imam Zarnuji}

Imam Zarnuji (Zarnuji) merupakan sebutan populer dari Burhan al-Din al-Zarnuji. Ia adalah seorang ulama Hanafiah yang hidup seputar abad ke-7 H./ke-13 M. Zarnuji adalah murid Burhan al-Din Ali b. Abi Bakr al-Farghani al-Marghinani -pengarang kitab Hidayah fi al-Furu'i alFiqhi- yang meninggal tahun 593 H./1197 M. ${ }^{1}$ Al-Marghinani -guru Zarnuji- merupakan salah satu keluarga Imam Hanafi yang lahir di kota Marghinan di Farghana. ${ }^{2}$

Zarnuji hidup di masa dinasti Abbasiyah di Irak (750-1258 M.), pada periode kelima dinasti Abbasiyah di zaman al-Muntashir (1226-

\footnotetext{
${ }^{1}$ Ahmad al-Santawi, dkk., Dairah al-Ma'arif al-Islamiyah,cet. Ke 10 (Beirut: Lajnah Tarjamah, 1933), 345

${ }^{2}$ Van Donzel, Islamic Desk Reference (New York: Leiden, 1994), 249 
1242 M.). ${ }^{3}$ Waktu itu wilayah kekuasaan dinasti Abbasiyah sudah menyempit. Banyak daerah memerdekakan diri, melepaskan diri dari pusat. Mereka hanya menguasai daerah Baghdad saja. Ketika berbagai propinsi memisahkan diri, gejolak politik dalam negeri terjadi dan membuat perekonomian kian terpuruk. Moral yang semakin merosot juga memperparah keadaan. Guru kehilangan wibawa di mata murid. Dalam pengamatan Zarnuji, banyak pelajar tak mampu lagi mereguk saripati ilmu, akibat metode belajarnya yang salah.

Zarnuji sangat menekankan bahwa ilmu yang wajib dipelajari adalah ilmu-ilmu agama saja, dimana hal itu akan bermanfaat bagi kehidupan keagamaan dalam setiap keadaan. Ilmu-ilmu yang dimaksud adalah ilmu-ilmu yang bisa menyelamatkan manusia dari kekufuran, antara lain: ilmu keimanann, shalat, zakat, puasa, dan lain sebagainya. ${ }^{4}$ Zarnuji menganggap bahwa ilmu tauhid dan ilmu fiqih adalah ilmu yang paling bermanfaat dan paling dibutuhkan dalam kehidupan sehari-hari, dan hukum mempelajarinya adalah fardhu 'ain. ${ }^{5}$

Dalam pada itu mempelajari ilmu-ilmu agama yang hanya bermanfaat pada situasi-situasi tertentu, seperti ilmu yang terkait dengan menjenguk orang sakit, shalat jenazah, dan sejenisnya, hukumnya fardhu kifayah. ${ }^{6}$ Zarnuji juga melarang pelajaran filsafat dan ilmu-ilmu sejenis mantiq dan semacamnya. ${ }^{7}$ Prinsip-prinsip Zarnuji yang demikian sudah tentu dapat mempengaruhi eksistensi dan substansi kitab Ta'lim alMuta'llim yang dikarangnya, yang mana sangat bersifat sufistik dan bila dipahami -sekilas- oleh manusia modern terkesan membelenggu (hegemonik).

Mengenai karya Zarnuji, Ta'lim al-Muta'llim merupakan satusatunya karya populer Zarnuji yang dapat diketahui dan masih ada sampai sekarang. Ta'lim al-Muta'llim merupakan salah satu dari deretan

3 Irsyad Zamjani, “Ta'lim al-Muta'allim: Ideologisasi Ilmu Gaya Abad Pertengahan", sebuah cataan kaki, dalam Ulumuna: Jurnal Studi Islam dan Masyarakat (Mataram: Stain Mataram, Juli-Desember 2003), 406.

${ }^{4}$ Syekh Ibrahim, Syarah Ta'lim al-Muta'allim Thariq al-Ta'allumi (Surabaya: AlHidayah, tanpa tahun), 4

${ }^{5}$ Syekh Az Zarnuji, Pedoman Belajar Pelajar dan Santri, Edisi Indonesia terj. Noor Aufa Shidiq dari "Ta'lim al-Muta'allim" (Surabaya: Al-Hidayah, tanpa tahun), 1

${ }^{6}$ Syekh Az Zarnuji, Pedoman Belajar Pelajar dan Santri, 6

7 Syekh Ibrahim, Syarah Ta'lim al-Muta'allim Thariq al-Ta'allumi, 7 
kitab kuning yang banyak dipelajari dan menjadi pedoman santri di pesantren. Di pesantren-pesantren Jawa, kitab-kitab klasik keagamaan karya ulama-ulama terdahulu (sebut kitab kuning) telah lama menjadi literatur pokok dalam pembelajaran agama. Kajian kitab kuning telah menjadi tradisi pesantren selama berabad-abad. ${ }^{8}$

Menurut Zarnuji, ilmu adalah suatu sifat yang dapat dijadikan sebagai sarana untuk menuju kebenaran, sehingga pemiliknya dapat mengetahui sesuatu dengan sempurna. Sifat tersebut merupakan keutamaan dan kemuliaan dari Allah SWT. yang hanya diberikan kepada manusia dan tidak diberikan kepada makhluk-Nya yang lain, karena manusia adalah makhluk yang paling mulia dan patut mendapatkan kehormatan dari para malaikat. Zarnuji mengutip sebuah syair dari Syekh Muhammad bin Hasan bin Abdillah yang menjelaskan bahwa ilmu merupakan hiasan dan petunjuk bagi pemiliknya. ${ }^{9}$

Dalam pandangan Zarnuji, ilmu dilihat dari sisi asal dan kegunaannya yang bersifat pragmatis dan penuh dengan nilai-nilai moral. ${ }^{10}$ Ilmu bagi Zarnuji adalah materi yang diperoleh dari pemberian Allah SWT. Ilmu adalah milik Tuhan yang bersih dan suci. Ini berbeda dengan pandangan kebanyakan orang yang melihat ilmu dari sudut proses perolehannya, yaitu dari hasil penelitian manusia.

Zarnuji menganjurkan bagi peserta didik tingkat dasar untuk mempelajari pelajaran baru sepanjang kira-kira ia mampu menguasainya dengan hanya mengulang dua kali ${ }^{11}$-tanpa harus bersusah payah, serta menambahnya sedikit demi sedikit sehingga setelah banyak pun masih mampu menguasainya dengan baik, karena dengan begitu, secara bertahap pelajaran tersebut akan bertambah dengan tanpa melalaikan pelajaran yang lalu.

Zarnuji menunjukkan proses belajar dalam kitabnya Ta'lim alMuta'allim. Menurutnya proses belajar yang ideal adalah sebagai berikut.

\footnotetext{
${ }^{8}$ Moeslim Abdurrahman, Islam Transformatif, Cet. Ke 3 (Jakarta: Pustaka Firdaus, 1997), 53

${ }^{9}$ Syekh Zarnuji, Pedoman Belajar..., 4

${ }^{10}$ Syekh Zarnuji, Pedoman Belajar..., 5

${ }^{11}$ Syekh Zarnuji, Pedoman Belajar..., 55

Jurnal Pendidikan Agama Islam

Volume 02 Nomor 02 November 2013

Hal 204 - 221
} 
Pertama, Selain tujuan (niat) yang baik ketika hendak belajar, seorang pelajar harus memiliki kesungguhan ${ }^{12}$ demi tercapainya tujuan (niat) dalam pendidikan. Kesungguhan di sini dapat diterapkan dalam memahami keterangan guru atau pelajaran yang sedang dipelajari dengan hanya memfokuskan pikiran dan perhatian pada pelajaran tersebut. Setelah proses pertama terjalani, maka dilanjutkan pada proses selanjutnya. Artinya, Zarnuji tidak mengizinkan peserta didik untuk mencampur-adukkan proses yang satu dengan yang lainnya. Oleh karenanya, ia pun melarang peserta didik untuk menulis pelajaran yang belum difahami, karena menurutnya hal ini dapat mengurangi kecerdasan.

Kedua, setelah memahami pelajaran dengan bersungguhsungguh, maka proses selanjutnya adalah menulis. ${ }^{13}$ Menulis di sini bukan berarti hanya sekedar menulis apa yang diberikan oleh guru, akan tetapi yang dimaksud menulis di sini adalah mencatat pelajaran yang telah diberikan guru dengan memahami dan menyimpulkan sendiri.

Ketiga, proses selanjutnya adalah mengulang-ulang pelajaran yang telah dipelajari, baik yang baru saja dipelajari, atau kemarin bahkan lusa. ${ }^{14}$ Pengulangan ini dilakukan dalam rangka mempermudah hafalan. Menghafal merupakan salah satu ciri dari cerdasnya seseorang. Dengan menghafal sedikit demi sedikit maka semakin lama akan bertambah banyak. ${ }^{15}$ Semakin banyak hafalan seseorang, maka semakin banyak ilmu yang telah dikuasainya.

Keempat, proses atau metode yang perlu dilakukan dalam pendidikan (belajar) adalah Musyawarah. ${ }^{16}$ Hal ini dilakukan dalam rangka memantapkan pemahaman terhadap suatu pelajaran. Musyawarah diartikan sebagai dialog atau diskusi untuk mencari mufakat. Musyawarah merupakan suatu rangkaian aktifitas belajar yang amat diperlukan, sebab dalam proses ini para peserta didik tidak bisa melepaskan diri dari perdebatan atau tukar fikiran serta selalu melibatkan teman karena tidak bisa dilakukan sendiri.

${ }^{12}$ Syekh Zarnuji, Pedoman Belajar..., 13

${ }^{13}$ Syekh Zarnuji, Pedoman Belajar..., 31

${ }^{14}$ Syekh Zarnuji, Pedoman Belajar..., 71

${ }^{15}$ Syekh Zarnuji, Pedoman Belajar..., 91

${ }^{16}$ Syekh Zarnuji, Pedoman Belajar..., 18. 
Kelima, proses dalam belajar adalah Taammul (bercita-cita; berfikir secara sungguh-sungguh; berencana sebelum berbuat; dll.). Taammul dapat dilakukan untuk memecahkan masalah yang dianggap sulit dan rumit ketika belajar. Dalam hal ini Zarnuji menghimbau kepada peserta didik yang hendak berbicara dalam mengutarakan pendapat, agar peserta didik tersebut ber-taammul terlebih dahulu guna memikirkan dan berencana terhadap apa yang hendak ia bicarakan, supaya bahan pembicaraannya dapat terarah dengan baik dan diterima oleh orang lain. ${ }^{17}$ Ber-taammul amat dianjurkan dalam Islam ketika ingin memulai setiap perbuatan.

Zarnuji menjelaskan bahwa setiap orang berhak memiliki kesempatan yang sama dalam menuntut ilmu, sebagaimana disebutkan dalam kitabnya bahwa masa menuntut ilmu adalah seumur hidup. Ini sesuai dengan hadits Nabi SAW. "'Uthlubul 'Ilma minal Mahdi ilal Lahdi" (carilah ilmu mulai dalam kandungan sampai berada di liang lahad). Zarnuji menegaskan bahwa waktu mencari ilmu itu tidak terbatas; yakni mulai sejak bayi sampai ke liang lahad. ${ }^{18}$

Zarnuji juga menetapkan beberapa waktu yang baik untuk belajar, karena menurutnya waktu-waktu tersebut dapat membawa berkah. Misalnya, Zarnuji mengajarkan kepada setiap peserta didik untuk memulai belajar pada hari Rabu. Argumen ini diambil dari beberapa ulama sebelumnya, antara lain adalah Syekh Burhanuddin (guru Zarnuji) dan Abu Hanifah, dengan alasan bahwa hari Rabu adalah hari yang penuh berkah bagi orang Mukmin. Hal ini juga berdasarkan pada hadits Nabi Muhammad SAW. yang menyatakan bahwa apa saja yang dimulai pada hari Rabu itu dapat sempurna. ${ }^{19}$ Di samping itu waktu yang paling utama untuk belajar adalah waktu sahur serta waktu antara maghrib dan isya'. ${ }^{20}$

Mengenai sikap yang harus dimiliki oleh seorang pencari ilmu, Zarnuji mengutip kata-kata Ali r.a. bahwa syarat untuk mendapatkan ilmu ada enam, antara lain: kecerdasan, tamak (rakus kepada ilmu), sabar (tabah), biaya cukup, petunjuk guru (pembimbing), dan sepanjang masa. ${ }^{21}$

${ }^{17}$ Syekh Zarnuji, Pedoman Belajar..., 57.

${ }^{18}$ Syekh Zarnuji, Pedoman Belajar..., 81

${ }^{19}$ Syekh Zarnuji, Pedoman Belajar..., 54-55

${ }^{20}$ Syekh Zarnuji, Pedoman Belajar..., 81

${ }^{21}$ Syekh Zarnuji, Pedoman Belajar..., 21

Jurnal Pendidikan Agama Islam

Volume 02 Nomor 02 November 2013

Hal $206-221$ 
Akan tetapi enam syarat tersebut tidak menjamin atas kesuksesan peserta didik untuk mendapatkan ilmu yang bermanfaat, kecuali jika selama proses belajar sampai selesai peserta didik memiliki akhlak (moral) yang terpuji dan menjauhi akhlak yang tercela; terutama sombong (alTakabbur), sebab ilmu tidak akan didapat dengan kesombongan. Zarnuji menyatakan bahwa setiap peserta didik harus memiliki sikap yang terpuji, antara lain: 1. Memuliakan guru, 2. Mengagungkan ilmu, 3. Menghormati Teman dan Bersikap Asih, 4. Bersikap Wira'i, 5. Tawakkal, 6. Menghadap Kiblat .

Zarnuji menyebutkan beberapa hal yang dapat mempengaruhi ingatan yang berkaitan dengan hafalan. Di antara hal-hal yang dapat memperkuat dan mempermudah hafalan adalah: bersungguh-sungguh, rajin, ulet, mengurangi makan, bersiwak, minum madu, makan dua puluh satu buah anggur merah setiap hari sebelum makan, shalat malam, dan rajin membaca al-Quran. ${ }^{22}$

Omar M. al-Toumy al-Syaibani ${ }^{23}$ mencatat, bahwa menurut Zarnuji hal-hal yang bisa memperkuat ingatan adalah: mengulangi berkali-kali apa yang telah dihafal, mengurangi makan, sembahyang waktu malam dan membaca al-Qur'an, serta menjauhi segala macam maksiat dan kesedihan. Dalam pesan terakhir ini, berarti seorang pelajar harus tabah akan segala musibah yang menimpa, sebab musibah itu datangnya dari Allah dan pasti selalu ada jalan keluarnya, sehingga seseorang tidak boleh terlena dalam kesedihan.

Di samping memperkuat hafalan, Zarnuji juga menyebutkan beberapa hal yang dapat menyebabkan lupa, antara lain: Perbuatan maksiat, banyak dosa, sibuk dengan urusan dunia, makan ketumbar yang masih basah, makan buah apel yang asam, melihat orang disalib, membaca tulisan di batu nisan, berjalan di antara dua unta yang bergandeng serta membuang kutu rambut hidup-hidup ke tanah. ${ }^{24}$

Tujuan belajar yang dimaksud oleh Zarnuji bersifat spiritualsufistik dan berorientasi pada kepentingan akhirat. Hal ini mengacu pada Syair Abu Hanifah yang diterimanya dari Syekh Imam al-Ajal al-Anshari

${ }^{22}$ Syekh Zarnuji, Pedoman Belajar..., 101

23 Omar M. al-Toumy al-Syaibani, Falsafah Pendidikan Islam, terj. Hasan Langgulung (Jakarta: Bulan Bintang, 1979), 577

${ }^{24}$ Omar M. al-Toumy al-Syaibani, Falsafah Pendidikan Islam, 104. 
dan kemudian menjadi pedomannya; "Barang siapa yang belajar (mencari ilmu) hanya untuk tujuan akhirat, maka ia akan mendapat (memperoleh) kebahagiaan, karunia, dan petunjuk dari Tuhan. Sebab, dengan niat yang demikian itu, ia dapat menuju kebenaran dan memperoleh fadlal (keutamaan). Barang siapa mencari ilmu dengan tujuan agar dihormati dan dimuliakan oleh manusia, maka ia akan mengalami kerugian besar." 25

Tujuan pendidikan menurut Zarnuji adalah mencari keridlaan Allah SWT, memuliakan akal, mensyukuri nikmat Allah SWT, menjaga kesehatan badan dalam rangka mencapai kepentingan akhirat. Tujuan pendidikan Zarnuji bukan untuk mencari kemuliaan di sisi manusia dan bukan untuk mencari harta benda duniawi. Konsep pendidikan Zarnuji diarahkan untuk kepentingan keagamaan dan mencari ridho Allah SWT serta untuk kepentingan manusia pada kehidupan setelah kematian. Konsep pendidikan Zarnuji tidak berorientasi pada kepentingan keidupan di dunia.

\section{Konsep Pendidikan Paulo Freire}

Paulo Freire (Freire) lahir pada tanggal 19 September 1921 M. di Recife, sebuah kota pelabuhan di Timur laut Brazil. ${ }^{26}$ Sejak kecil, ia sudah diajarkan oleh orang tuanya untuk menghargai pendapat dan pilihan orang lain, dan hal itu memberikan pengaruh yang sangat besar terhadap filsafat pendidikannya. Kehidupan ekonomi orang tua Freire tergolong kelas menengah, tetapi karena suatu musibah, mereka menjadi miskin, sehingga sering mengalami kekurangan dalam hal finansial. Dengan begitu Freire benar-benar mengetahui dan pernah merasakan betapa tidak enaknya lapar.

Ketika masih kanak-kanak, Freire bersumpah akan membaktikan nıаupnya unгuк meıаwan кегараran aan memoela каum mısкın supaya tidak akan ada anak lain yang merasakan kelaparan dan penderitaan sebagaimana yang pernah dialaminya. ${ }^{27}$ Pada tahun 1944 M., di usianya

${ }^{25}$ Syekh Zarnuji, Pedoman Belajar..., 12

${ }^{26}$ Firdaus M. Yunus, Pendidikan Berbasis Realitas Sosial: Paulo Freire \& Y.B. Mangunwijaya (Yogyakarta: Logung Pustaka, 2004), 22

${ }^{27}$ Yunus, Pendidikan Berbasis Realitas Sosial:..., 22. 
yang ke 23 tahun, Freire melangsungkan pernikahan dengan Elza Maia Costa Olivera, seorang guru sekolah dasar yang kemudian menjadi kepala sekolah dari Recife. Dari pernikahan tersebut mereka mendapatkan tiga orang putri dan dua orang putra. ${ }^{28}$

Setelah keadaan ekonomi keluarganya membaik, Freire berhasil menyelesaikan sekolahnya dan menempuh pendidikan di Fakultas Hukum Universitas Recife. Di sana Freire belajar filsafat dan psikologi, di samping itu ia juga bekerja sebagai instruktur bahasa Portugis di sebuah sekolah lanjutan. Selama kuliah Freire banyak membaca karyakarya pendahulunya seperti Sartre, Althusser, Mounier, Ortega Y. Gasset, Unamuno, Martin Luther King Jr, Che Guevara, Fromm, Mao Tse Tung, Marcuse, dan sebagainya, ${ }^{29}$ yang semua itu berpengaruh kuat pada filsafat pendidikannya. Selanjutnya pada tahun 1959 M. ia mendapat gelar doctor dari University of Recife. ${ }^{30}$

Materi Pendidikan Freire bersifat kontekstual, artinya berisi tentang realitas sosial masyarakat. Pendidikan kontekstual adalah sebuah teori dan model pendidikan yang mengupayakan peserta didik untuk menjadi subjek dalam rangka menjawab persoalan-persoalan yang muncul dalam realitas sosial. Pendidikan bisa mengambil kesadaran sebagai suatu titik tolak yang menampilkan sesuatu yang oleh Freire disebut 'arkeologi kesadaran, ${ }^{31}$ yakni suatu pengujian atas pemikiran manusia yang menemukan keadaan sadar. Freire menekankan peran berfikir dalam pembuatan kembali dunia. Penelitian tersebut memungkinkan kesadaran mengambil sikap aktif terhadap dunia. Freire dengan arkeologi kesadaran- ingin menemukan kembali sejarah dan kebudayaan.

Pendidikan yang bermuatan materi ajar yang bersifat kontekstual, mengarahkan pada peserta didik untuk berinteraksi dengan dunianya,

${ }^{28}$ Denis E. Collins S.J, Paulo Freire; Kehidupan, Karya \&Pemikirannya, cet. 2, terj. Henry Heyneardhi \& Anastasia P. (Yogyakarta: Pustaka Pelajar, 2002), 8

29 Paulo Freire, Politik Pendidikan, Kebudayaan, Kekuasaan, dan Pembebasan, Pengantar Penerbit, cet. 3, terj. Agung Prihantoro dan Agung Arif Fudiyartanto (Yogyakarta: Pustaka Pelajar, 2002), xx

${ }^{30}$ Made Pramono, "Menyelami Spirit Epistemologi Paulo Freire", dalam Listiyono Santoso, dkk., Epistemologi Kiri (Yogyakarta: Ar-Ruzz, 2003), 127

${ }^{31}$ Yunus, Pendidikan Berbasis Realitas Sosial:..., 43-44 
karena tugas pendidikan adalah memproblematisasi realitas sosial menjadi bagian daripada manusia sebagai peserta didik. Freire dalam pedagoginya membuat tiga skema dalam merumuskan pendidikan kontekstual. Pertama, investigasi, yaitu pengujian dan penemuan kesadaran manusia yang bersifat takhayul, naif, dan kritis. Kedua, tematisasi, yaitu pengujian semesta tematis dengan reduksi; penemuan tema-tema generatif yang baru, yang tersirat dalam tema-tema sebelumnya. Ketiga, problematisasi; penemuan situasi-situasi rumit dan tindakan-tindakan limit yang mengarah pada aksi otentik tindakan kultural permanen untuk pembebasan. ${ }^{32}$

Pendidikan dengan materi ajar berupa realitas (masalah) sosial memposisikan manusia (peserta didik) pada kondisi menghadapi dan menyelesaikan berbagai masalah sosial serta menegaskan bahwa manusia adalah makhluk yang berada dalam proses menjadi (becoming), dan tidak pernah selesai, atau sebagai makhluk yang tidak pernah sempurna dalam menghadapi realitas. Manusia mengetahui bahwa dirinya adalah makhluk yang tak pernah tuntas, mereka sadar akan ketidaksempurnaannya, dan karena itu pendidikan sebagai bentuk pengejawantahan yang khas manusiawi. Sifat belum selesai dari manusia dan sifat terus berubahnya realitas mengharuskan pendidikan sebagai kegiatan yang terus berlangsung tanpa akhir (in never ending process).

Pendekatan yang dilakukan Freire dalam proses implementasi pendidikannya adalah bersifat dialogis. Pendidikan dialogis merupakan upaya penolakan Freire terhadap pendidikan 'gaya bank' (tradisional), yang telah menjadikan pendidikan sebagai ajang monopoli guru terhadap siswa di sekolah. Dalam upaya counter terhadap hal tersebut, seharusnya guru dan siswa menjadi mitra dialog dalam memecahkan segala persoalan, bukan membuat jarak antara guru dan siswa, karena dengan adanya jarak akan membuat peluang penindasan guru terhadap siswa terbuka lebar.

Pendidikan gaya bank (banking concept) diibaratkan Freire sebagai sebuah kenyataan dimana guru menabungkan ilmunya kepada murid secara sepihak. Guru menceritakan tentang objek-objek pengetahuan, sementara murid dengan patuh mendengarkannya tanpa ada

\footnotetext{
${ }^{32}$ Collins S.J, Paulo Freire; Kehidupan, Karya \&Pemikirannya, 150-151
} 
nilai kritis sedikit pun. Guru membicarakan suatu realitas seolah-olah menjadi sesuatu yang kaku, statis, tidak bergerak, terpisah satu sama lain, dan dapat diramalkan. ${ }^{33}$

Menurut Freire, ciri yang paling menonjol dari model pendidikan bercerita ini adalah kemerduan kata-kata, bukan kekuatan pengubahnya. Misalnya "empat kali empat adalah enambelas", "Ibukota Indonesia adalah Jakarta". Murid-murid mencatat, menghafal dan mengulangi ungkapan kata-kata ini tanpa memahami apa arti sesungguhnya dari "empat kali empat" dan "Ibukota Indonesia" bagi rakyat Indonesia.

Model pendidikan bercerita -dengan guru sebagai penceritanyamengarahkan murid-murid untuk menghafal secara mekanis apa isi pelajaran yang diceritakan. Murid seolah hanya sebagai bejana kosong yang siap diisi secara patuh oleh guru. Ironisnya, semakin penuh bejana itu diisi, yang terjadi adalah tumpahnya pengetahuan atau semakin bebalnya otak murid, dan akhirnya hanya menjadi konsumen pengetahuan tanpa berperan menjadi produsen sama sekali.

Pendidikan, dimana murid diposisikan sebagai celengan bagi guru yang menabung inilah yang dinamakan Freire sebagai pendidikan gaya bank. Pada pendidikan gaya ini, ruang gerak murid hanya terbatas sebagai penerima, pencatat, dan penyimpan pengetahuan. Memang benar, dalam hal ini murid akan efektif dalam mencatat dan menyimpan pengetahuan, tetapi ia akan pasif dan miskin dalam hal daya cipta dan daya ubah pengetahuan. ${ }^{34}$ Akibatnya, murid akan sulit berperan dalam menemukan pengetahuan (discovery of knowledge); padahal usaha untuk mencari dan menemukan pengetahuan adalah praktek empiris yang diharapkan di dalam proses pendidikan.

Lebih rinci, Freire menyebutkan kriteria-kriteria dari pendidikan "gaya bank" sebagai berikut: 1. Guru mengajar, murid diajar, 2. Guru tahu segalanya, murid tidak tahu apa-apa, 3. Guru berfikir, murid difikirkan, 4. Guru bercerita, murid patuh mendengarkan, 5. Guru mengatur, murid diatur, 6. Guru memilih dan memaksakan pilihannya, murid menyetujui, 7. Guru berbuat, murid membayangkan dirinya

\footnotetext{
${ }^{33}$ Paulo Freire, Pendidikan Kaum Tertindas, cet. 3, terj. Otomo Dananjaya (Jakarta: LP3ES, 2000), 49

${ }^{34}$ Paulo Freire, Pendidikan Kaum Tertindas, 50-51
} 
berbuat sesuai gurunya, 8 . Guru memilih apa yang akan diajarkan, murid menyesuaikan diri, 9. Guru mengacaukan wewenang ilmu pengetahuan dengan wewenang jabatannya dan menghalangi kebebasan murid, 10. Guru adalah subjek dalam proses belajar, murid adalah objeknya. ${ }^{35}$

Pendidikan dengan gaya tersebut di atas amatlah hegemonik, dimana kreatifitas peserta didik bisa diberangus lewat praksis otoritas guru. Pada akhirnya guru pun bertindak menindas sang murid dengan tidak memberikan kebebasan berekspresi/ beraspirasi akan segala unekuneknya yang mungkin sangat mengganggu dalam memori otaknya. Murid akan menjadi tumpul daya kreasinya jika pendekatan monolog (gaya bank) tersebut diterapkan dalam pendidikan. Pendidikan justru menjadi alat penindasan dan bukan penyadaran kritis serta pembebasan manusia untuk mencapai harkat kehidupan yang manusiawi.

Oleh karena itu, harus dilakukan reformasi dalam hal pendidikan. Bagi Freire yang harus dilakukan dalam pendidikan adalah: 1. Metode yang aktif, dialogis, kritis, dan menggugah sikap kritis; 2. Mengubah isi program pendidikan; 3. Menggunakan teknik-teknik seperti pemilahmilahan tema. Dengan demikian, metode yang diprioritaskan Freire dalam pendidikan adalah dialog, ${ }^{36}$ yang merupakan hubungan horizontal antar manusia.

Satu-satunya alat paling efektif dalam sebuah pendidikan yang manusiawi (humanis) adalah adanya hubungan timbal balik yang permanen yang berbentuk dialog. Dalam pendidikan yang memberikan penyadaran, pembebasan, dan pemanusiaan manusia ini, penindasan tidak bisa lagi menjadi alat bagi guru untuk memanipulasi siswanya, karena pendidikan di sini mengupayakan kesadaran kepada siswa; kesadaran untuk bebas dan mencapai harkat kemanusiaan.

Dialog merupakan kebutuhan eksistensial manusia. Dialog adalah penggunaan bahasa/ kata yang disusun berdasarkan refleksi dan aksi. Kata yang diucapkan tanpa tindakan adalah verbalisme, ${ }^{37}$ dan tindakan tanpa refleksi merupakan aktivisme. Dalam analisis Freire, dialog yang

\footnotetext{
${ }^{35}$ Paulo Freire, Pendidikan Kaum Tertindas, 51-52

36 Paulo Freire, Education for Critical Conciousness, ((New York: Continuum $\mathrm{Pu}$

${ }^{37}$ Paulo Freire, Pendidikan Kaum Tertindas, 72
} 
penuh harapan merupakan tindakan revolusioner, sebagai pengetahuan empiris yang bertemu dengan pengetahuan kritis.

Bagi Freire, tak boleh ada pemisahan antara aksi dan refleksi. Freire menyamakan dialog dengan tindakan revolusioner. Melalui dialog dan komunikasi bahasa, siswa dianggap bertanggung jawab dalam proses pembelajaran mereka sendiri, dan lalu menjadi mitra guru dalam belajar. Freire menegaskan bahwa dialog merupakan hal yang esensial bagi proses penyadaran. Ia menggarisbawahi potensi yang luas dari dialog dan dengan bersemangat mempertahankan kekuatan bahasa sebagai alat yang mampu menanamkan dominasi maupun kebebasan. Tentu saja dialog dapat membawa seseorang untuk memaknai dunia dan mendorong transformasi sosial dan pembebasan.

Freire juga tanpa malu memegang nilai-nilai seperti cinta kasih sebagai esensi dialog; "If I do not love the world; if I do not love life; if I do not love people, I cannot enter into dialogue" (jika aku tidak mencintai dunia; jika aku tidak mencintai hidup; jika aku tidak mencintai rakyat, aku tidak dapat terlibat dalam dialog). ${ }^{38}$ Menurut Freire, dialog mengandung arti bersikap kritis yang berisi tentang objek-objek dan subjek-subjek dialog. Dengan begitu dialog harus berjalan bebas, efektif, dan penuh harapan. ${ }^{39}$

Konteks dialog yang teoritis pada dasarnya menghadirkan fakta berupa keadaan nyata yang secara kritis bisa dianalisis. Analisis ini melibatkan pengujian atas abstraksi dengan cara merepresentasikan realitas yang konkrit, terutama dalam mencari pengetahuan yang kontekstual. Guru dan murid (sebagai subjek pengetahuan yang dialogis) berada pada posisi "setara" dalam proses penyelidikan terhadap objek. Dialog yang teoritis harus diaplikasikan ke dalam dataran praktis yang kontekstual (sesuai dengan realitas sosial yang terjadi dan aktual).

\footnotetext{
${ }^{38}$ Yunus, Pendidikan Berbasis Realitas Sosial:..., 47

39 Paulo Freire juga menegaskan bahwa semestinya pendidikan (pedagogi) itu menjadi sebuah harapan bagi setiap manusia (terutama peserta didik); harapan ke depan untuk mencapai cita-cita mulia dalam kehidupan. Mengenai pedagogi harapan, lihat Paulo Freire, Pedagodi Harapan: Menghayati Kembali Pedagogi Kaum Tertindas, cet. 5 (Yogyakarta: Kanisius, 2005)
} 
Dalam pandangan Freire, ${ }^{40}$ setidaknya ada lima (5) sikap (attitude) yang harus dimiliki dalam merealisasikan proses yang dialogis. Pertama, rasa cinta kasih. Dialog tidak akan terjadi tanpa adanya rasa cinta kasih yang mendalam terhadap dunia dan sesamanya. Cinta sekaligus menjadi dasar daripada dialog bahkan dialog itu sendiri. Kedua, sikap rendah hati. Dialog tidak akan terjadi bila sesama manusia saling menunjukkan ego kesombongannya. Dialog akan terjalin bila sesama manusia menyadari akan kekurangan masing-masing dan sadar bahwa manusia adalah makhluk yang belum selesai dan tidak sempurna, sehingga perlu hubungan yang dialogis dalam rangka menutupi kekurangan masing-masing.

Ketiga, adanya keyakinan yang mendalam terhadap diri manusia. Manusia yang dialogis yakin (percaya diri) akan diri dan manusia lain, sehingga tercipta sikap saling menghargai dalam praktek dialog. Rasa cinta kasih, rendah hati, dan keyakinan diri menjadi dasar dari proses dialog yang mengarah pada hubungan horizontal yang harmonis dan saling mempercayai. Keempat, sikap penuh harapan. Tanpa adanya harapan, mustahil terjadi dialog. Proses pendidikan yang tidak memberikan harapan akan menjadi suatu media kebisuan bagi peserta didik. Pendidikan harus penuh dengan harapan progresif yang logis dan realistis.

Kelima, sikap kritis. Dialog sejati tidak akan terwujud kecuali dengan melibatkan pemikiran kritis, pemikiran yang melibatkan suatu hubungan tak terpisahkan antara manusia dan dunia tanpa melakukan dikotomi antara keduanya, pemikiran yang memandang realitas sebagai proses dan perubahan (bukan entitas yang statis), pemikiran yang tidak memisahkan dirinya dari tindakan (tetapi senantiasa bergumul dengan masalah-masalah keduniawian tanpa rasa gentar dalam menghadapi sebuah resiko).

Dialog merupakan hubungan aku-anda, maka harus merupakan hubungan dua subjek. Apabila anda diperlakukan sebagai benda, maka dialog menjadi terganggu dan yang terjadi adalah penghancuran. Bagi Freire, berbagai sarana belajar bisa digunakan, asalkan tetap dalam bingkai dialogis. Freire juga menggunakan sarana berupa slide, film, atau

\footnotetext{
${ }^{40}$ Paulo Freire, Pendidikan Kaum Tertindas, 74-79
} 
poster dalam proses pendidikannya. Apabila berbagai sarana telah disiapkan, maka proses pendidikan pun dimulai dan materinya selalu dikaitkan dengan problematika sosial yang terjadi.

Konsep pendidikan Freire tidak ansich bersifat teoritis tetapi juga praktis. Hal itu dibuktikannya dengan gerakan kampanye melek huruf bersama timnya ke beberapa belahan dunia ketiga. Dalam pada itu ada beberapa tujuan yang ingin dicapai Freire dalam ide dan gerakan pendidikannya. Pendidikan Freire -antara lain- bertujuan untuk penyadaran manusia akan realitas sosialnya. Dalam rangka itu Freire melihat bahwa "penyadaran" (conscientizacao) merupakan inti daripada pendidikan. Pendidikan harus berisi materi ajar yang terkait dengan fenomena aktual dari realitas sosial masyarakat, sehingga melalui pendidikan peserta didik menjadi sadar akan realitas sosial sekitarnya bahkan sadar akan realitas dunia.

Dengan kesadaran sebagai tujuan dari pendidikan, diharapkan peserta didik (manusia umumnya) sadar akan realitas diri dan dunianya. Realitas manusia yang sering mengalami ketertindasan atau penindasan, diharapkan disadari melalui proses pendidikan yang salah satu metodenya adalah dialogis. Setelah sadar, manusia diharapkan bisa membebaskan diri dari segala bentuk kehidupan yang menindas, dan dari sini derajat kemanusiaan (humanis) akan bisa dicapai secara utuh.

Dalam banyak kesempatan Freire menyatakan bahwa pendidikan merupakan nilai yang paling vital bagi proses pembebasan manusia. Baginya pendidikan menjadi jalur permanen pembebasan, dan berada dalam dua tahap. Pertama, pendidikan menjadikan orang sadar akan penindasan yang menimpa mereka dan melalui gerakan praktis mengubah keadaan itu. Kedua, pendidikan merupakan proses permanen aksi budaya pembebasan. $^{41}$

Pendidikan pada dataran ini harus menjadi proses pemerdekaan, bukan penjinakan (domestifikasi) sosial sebagaimana yang sering terjadi dalam dunia ketiga (seperti Brazil), yakni pendidikan sering dijadikan alat untuk melegitimasi kehendak penguasa terhadap rakyat yang tidak

${ }^{41}$ Paulo Freire, "Pendidikan yang membebaskan, Pendidikan yang Memanusiakan", dalam Omi Intan Naomi, Menggugat Pendidikan Fundamentalisme, Konserfatif, Liberal, dan Anarkhis (Yogyakarta: Pustaka Pelajar, 2001), 446-447 
berkuasa. Untuk itu pendidikan harus menjadi refleksi dan tindakan ${ }^{42}$ secara menyeluruh untuk mengubah realitas yang menindas menuju pembebasan.

Dalam Pedagogy of the Oppressed (pendidikan kaum tertindas), ${ }^{43}$ Freire melontarkan wacana pembebasan yang didasarkan pada keyakinan transformasi politik dan individu. Ia menekankan bahwa struktur, sistem, atau lembaga penindasan harus ditolak. Freire menggambarkan penindasan sebagai kondisi dimana "A" secara obyektif mengeksploitasi "B" atau merintangi usahanya untuk menegaskan diri sebagai seseorang yang bertanggung jawab. Antara penindas dan tertindas merupakan manifestasi dari perilaku dehumanisasi. Penindas didehumanisasikan oleh tindakan penindasan yang -bisa jadi- akan menghancurkan dirinya sendiri, sedangkan si tertindas didehumanisasikan oleh realitas penindasan yang mereka alami.

Freire berusaha mengarahkan pendidikan sebagai usaha untuk humanisasi diri dan sesama, yaitu melalui tindakan sadar untuk mengubah dunia. Humanisasi (memanusiakan manusia) dalam pandangan Freire merupakan suatu praktek hidup untuk mencapai keadaan manusia yang sejati karena sesuai dengan fitrahnya. Akan tetapi proses humanisasi selalu diiringi dengan kondisi dehumanisasi (tidak manusiawi) yang memang harus diperangi. Dalam konteks yang konkrit dan obyektif, masalah humanisasi atau dehumanisasi merupakan kemungkinan yang selalu tersedia bagi seseorang sebagai makhluk "belum selesai" yang menyadari ketidaksempurnaannya. ${ }^{44}$

Humanisasi merupakan fitrah manusia, namun ia sering diingkari oleh manusia sendiri (terutama oleh kaum penindas); dan justru karena adanya pengingkaran tersebut, humanisasi menjadi disadari. Pengingkaran terhadap humanisasi biasanya berupa perlakuan tidak adil, pemerasan, penindasan, dan kekejaman kaum penindas. Humanisasi diakui sebagai bentuk kerinduan kaum tertindas akan kebebasan dan keadilan, serta perjuangan mereka untuk meraih kembali harkat kemanusiaan mereka yang hilang.

${ }^{42}$ Paulo Freire, Pendidikan Kaum Tertindas, 44

${ }^{43}$ Paulo Freire, Pendidikan Kaum Tertindas, 28

${ }^{44}$ Paulo Freire, Pendidikan Kaum Tertindas, 11 


\section{Integrasi Pendidikan Zarnuji dan Freire: Pendidikan Islam yang Ideal}

Pem1kıran pendıdıkan Larnujı terdengar gaungnya pada wilayah yang berkutat pada persoalan moral-transendental (ibadah kepada Allah) untuk kebahagiaan akhirat. Sementara itu pendidikan Freire terdengar gaungnya pada wilayah humanisasi dan liberasi. Akibatnya, konsep pendidikan Freire dinilai membebaskan (liberate) tetapi kurang bermoral, sedangkan konsep pendidikan Zarnuji dinilai penuh dengan pesan moral tetapi membelenggu (hegemonik). Oleh karena itu, urgen jika terjadi pemaduan (integrasi) antara konsep pendidikan Zarnuji dan Freire.

Menurut Kuntowijoyo, ${ }^{45}$ selama ini umat Islam belum mendasarkan gerakannya pada elaborasi yang mendalam tentang realitas sosial yang objektif. Umat Islam masih berkutat pada kesadaran subjektif-normatif, sehingga mereka baru tampil dalam realitas subjektif. Usaha untuk membentuk pribadi muslim, jama'ah, komunitas, dan umat, misalnya, hanya didorong oleh kesadaran normatif yang subjektif, sehingga mereka (umat Islam) kurang siap merespon berbagai tantangan perubahan sosial yang empiris, yang terjadi di masyarakat kontemporer.

Oleh karena itu, perlu adanya pengembangan konsep pendidikan Islam yang tidak hanya berhenti pada dataran normatif, tetapi perlu dilihat secara filosofis dan empiris. Pencarian konsep pendidikan Islam yang ideal seperti tersebut di atas, menurut hemat penulis, bisa dilakukan melalui integrasi (pemaduan) antara konsep pendidikan Zarnuji dengan konsep pendidikan Freire, sepanjang tetap menjadikan Islam sebagai landasan sentral filosofis.

Hal itu sejalan dengan pemikiran Azyumardi Azra ${ }^{46}$, bahwa pola kajian dan teori pendidikan Islam pada hakikatnya berusaha mengembangkan konsepsi kependidikan Islam secara menyeluruh dengan bertitik pada sejumlah pandangan dasar Islam mengenai kependidikan dan mengkombinasikannya dengan pendidikan modern. Dengan

\footnotetext{
${ }^{45}$ Kuntowijoyo, Paradigma Islam: Interpretasi untuk Aksi (Bandung: Mizan, 1994), 182

${ }^{46}$ Azyumardi Azra, Pendidikan Islam dan Modernisasi (Jakarta: Logos, 1999), 9091
} 
demikian, hal ini menyarankan secara implisit adanya aspirasi di kalangan pemikir pendidikan Islam untuk melakukan terobosan intelektual demi merekonstruksi konsep pendidikan Islam dalam konteks dunia kontemporer. Oleh karena itu pendidikan Islam tidak boleh hanya berparadigma regresive oriented, tetapi juga perlu progressive oriented.

Jalaludin Rahmat menyatakan bahwa pendidikan Islam bukan sekedar proses penanaman nilai-nilai moral untuk membentengi diri dari akses negatif globalisasi. ${ }^{47}$ Lebih dari itu, yang paling urgen adalah bagaimana agar nilai-nilai moral yang telah ditanamkan pendidikan Islam tersebut mampu berperan sebagai kekuatan pembebas (liberating force) dari himpitan kemiskinan, kebodohan, dan keterbelakanagan sosial ekonomi dan budaya. Oleh karenanya kandungan pendidikan Islam harus bersifat holistik dari aspek-aspek kehidupan dan tidak perlu bersifat dikotomis antara pendidikan agama dan umum, sebab ilmu dalam pendidikan Islam sebenarnya bersifat utuh-integral-integratif.

Berpijak pada pemikiran di atas, yang urgen diangkat dalam diskursus pendidikan Islam saat ini adalah muatan pendidikan Islam sebagaimana yang tersirat dalam al-Quran. Dalam al-Quran surat Ali Imran ayat 110, tertulis "Engkau adalah umat terbaik yang diturunkan di tengah manusia untuk 'menegakkan kebaikan', 'mencegah kemungkaran', dan 'beriman kepada Allah','.

Dalam ayat tersebut di atas menyiratkan tiga pesan universal yang harus dilakukan oleh umat Islam, dan semestinya menjadi muatan dalam pendidikan Islam. Tiga pesan yang dimaksud adalah "menegakkan kebaikan" (liberasi), "mencegah kemungkaran" (humanisasi), dan "beriman kepada Allah" (transendensi). Pendidikan Islam jika ingin tetap eksis dalam kancah globalisasi, maka perlu menjadikan tiga muatan itu sebagai paradigma pendidikannya.

Dalam kaitan itu, konsep pendidikan Freire perlu diintegrasikan dengan konsep pendidikan Zarnuji. Konsep pendidikan Freire secara filosofis tidak bertentangan dengan nilai-nilai ajaran Islam yang memang menghendaki adanya liberasi dari kebodohan, kemiskinan, dan keterbelakangan. Sementara itu pendidikan Zarnuji mengandung nilainilai moral-etik yang berdimensi transendensi. Oleh karenanya, jika

${ }^{47}$ Jalaludin Rahmat, Islam Alaternatif (Mizan: Bandung, 1989), 3

Jurnal Pendidikan Agama Islam

Volume 02 Nomor 02 November 2013

Hal $218-221$ 
pendidikan Zarnuji diintegrasikan dengan pendidikan Freire, maka akan menjadi konsep pendidikan Islam yang ideal; pendidikan Islam yang berbasis moral-rasional; dan pendidikan Islam yang tidak bertentangan dengan spirit universal al-Quran, yakni humanisasi, liberasi, dan transendensi; dan ini tentu relevan dengan tuntutan zaman.

\section{E. Penutup}

Mengkaji pemikiran pendidikan Imam Zarnuji dan Paulo Freire memang amat menarik, karena keduanya memiliki kekuatan masingmasing. Imam Zarnuji merupakan seorang filosof muslim dalam hal pendidikan yang ide-idenya kental dengan pesan-pesan moral. Menurutnya, selama ini peserta didik banyak menemukan kegagalan dalam hal kompetensi moral. Sehingga banyak alumni-alumni lembaga pendidikan yang cerdas tetapi kurang bermoral. Sementara itu Paulo Freire merupakan filosof pendidikan Baarat yang ide-idenya kental dengan pesan-pesan pembebasan dalam pendidikan. Pendidikan harus memanusiakan manusia. Pendidikan harus membebaskan dan dapat menyelesaikan realitas problem sosial kemanusiaan.

Pendidikan Zarnuji terdengar gaungnya pada wilayah yang berkutat pada persoalan moral-transendental untuk kebahagiaan akhirat. Sementara itu pendidikan Freire terdengar gaungnya pada wilayah humanisasi dan liberasi. Pendidikan Freire punya keunggulan dari sisi rasionalitas dan skill tanpa ditunjang dengan pengayaan moral, dalam kenyataannya hanya menghasilkan manusia yang cerdas tetapi kurang peka terhadap etika dan moral. Sementara pendidikan Zarnuji punya keunggulan dari segi moralitas tetapi kurang pengedepanan aspek rasionalitas, dalam kenyataannya kurang peka dan tidak begitu respon terhadap perkembangan zaman. Dengan demikian sangat ideal jika konsep pendidikan Zarnuji diintegrasikan dengan konsep pendidikan Freire, agar tercapai pendidikan Islam berbasis etik-rasional atau moralintelektual. Dari pendidikan Zarnuji dapat diambil basic moralnya, sementara dari Freire dapat diambil metodologi keilmuannya. Sehingga 
terlahir konsep pendidikan yang bernilai liberasi dengan muatan moraltransendensi.

\section{DAFTAR PUSTAKA}

Ahmad al-Santawi, dkk., Dairah al-Ma'arif al-Islamiyah, cet. Ke 10 (Beirut: Lajnah Tarjamah, 1933)

Azyumardi Azra, Pendidikan Islam dan Modernisasi (Jakarta: Logos, 1999)

Denis E. Collins S.J, Paulo Freire; Kehidupan, Karya \&Pemikirannya, cet. 2, terj. Henry Heyneardhi \& Anastasia P. (Yogyakarta: Pustaka Pelajar, 2002)

Firdaus M. Yunus, Pendidikan Berbasis Realitras Sosial: Paulo Freire \& Y.B. Mangunwijaya (Yogyakarta: Logung Pustaka, 2004)

Irsyad Zamjani, “Ta'lim al-Muta'allim: Ideologisasi Ilmu Gaya Abad Pertengahan", sebuah cataan kaki, dalam Ulumuna: Jurnal Studi Islam dan Masyarakat (Mataram: Stain Mataram, Juli-Desember 2003)

Jalaludin Rahmat, Islam Alaternatif (Mizan: Bandung, 1989)

Kuntowijoyo, Paradigma Islam: Interpretasi untuk Aksi (Bandung: Mizan, 1994)

Moeslim Abdurrahman, Islam Transformatif, Cet. Ke 3 (Jakarta: Pustaka Firdaus, 1997)

Made Pramono, "Menyelami Spirit Epistemologi Paulo Freire", dalam Listiyono Santoso, dkk., Epistemologi Kiri (Yogyakarta: Ar-Ruzz, 2003)

Omar M. al-Toumy al-Syaibani, Falsafah Pendidikan Islam, terj. Hasan Langgulung (Jakarta: Bulan Bintang, 1979)

Paulo Freire, Politik Pendidikan, Kebudayaan, Kekuasaan, dan Pembebasan, Pengantar Penerbit, cet. 3, terj. Agung Prihantoro dan Agung Arif Fudiyartanto (Yogyakarta: Pustaka Pelajar, 2002)

Paulo Freire, Education for Critical Conciousness, ((New York: Continuum Publishing Company, 2000)

Paulo Freire, Pedagodi Harapan: Menghayati Kembali Pedagogi Kaum Tertindas, cet. 5 (Yogyakarta: Kanisius, 2005) 
Paulo Freire, "Pendidikan yang membebaskan, Pendidikan yang Memanusiakan", dalam Omi Intan Naomi, Menggugat Pendidikan Fundamentalisme, Konserfatif, Liberal, dan Anarkhis (Yogyakarta: Pustaka Pelajar, 2001)

Paulo Freire, Pendidikan Kaum Tertindas, cet. 3, terj. Otomo Dananjaya (Jakarta: LP3ES, 2000)

Syekh Ibrahim, Syarah Ta'lim al-Muta 'allim Thariq al-Ta'allumi (Surabaya: Al-Hidayah, tanpa tahun)

Syekh Az Zarnuji, Pedoman Belajar Pelajar dan Santri, Edisi Indonesia terj. Noor Aufa Shidiq dari "Ta'lim al-Muta'allim" (Surabaya: AlHidayah, tt.)

Van Donzel, Islamic Desk Reference (New York: Leiden, 1994). 